\title{
SUBSURFACE LOWER-MIDDLE MIOCENE BIOSTRATIGRAPHY OF RAS EL- USH OIL FIELD, G. ZEIT AREA, GULF OF SUEZ, EGYPT
}

\author{
Abdel Galil A. Hewaidy, Haitham M. Ayyad and Ahmed Abdallah \\ Geology Department, Faculty of Science, Al-Azhar University, Nasr City, Cairo, Egypt
}

\begin{abstract}
The Lower-Middle Miocene succession penetrated in four wells in Ras El Ush oil field (Ras El Ush 7,8,12 and 14), East G. Zeit, Gulf of Suez is examined in detail for its foraminiferal and nannofossil contents. The Rudeis, Kareem and Belayim formations are distinguished. One hundred and fifty-one foraminiferal and fortyfive nannofossils species are identified. Three planktonic foraminiferal and two nannofossils biozones are distinguished and integrated. The planktonic foraminiferal zones are Catpsydrax dissimilis (M3) of early Miocene (Burdigalian) age, Praeorbulina sicana (M5) of early-middle Miocene (Burdigalian-Langhian) age and Fohsella peripheroacuta (M7) of middle Miocene (Serravallian) age. The nannofossil biozones are Sphenolithus belemnos Zone (NN3) of early Miocene (Burdigalian) age and Helicosphaera ampliaperta Zone (NN4) of early Miocene (Burdigalian)to middle Miocene (Serravallian) aga.
\end{abstract}

Keywords: Ceramic tiles, Wadi El-Yatim, Wadi El-Tuleia, feldspar-sand, Eastern Desert, Egypt.

\section{INTRODUCTION}

Ras El Ush Oil Field was discovered in February 1995 by Marathon Oil Company. The production from the field started in Jan. 1996 by two wells (Ras El Ush-2 from the Matulla Formation and Ras El Ush-3 from the Nubia Sandstones). The total number of producing wells in the field now is four wells (Ras El Ush $3,7,8$ and 12). The main producing horizons of the field are the Nubia and Matulla reservoirs. The Ras El Ush Oil Field represents the nearest oil field to the hydrocarbon seepage in the area. It covers onshore and offshore area along Ras El Ush fault trend. Ras El Ush oilfield is located on the eastern side of Gebel El Zeit range. Gebel Zeit Range is one of the main topographic features on the southwestern shore of the Gulf of Suez (Fig.1). It extends for about $30 \mathrm{~km}$ from north to south close to the Gulf shore. Its average breadth is $5-6 \mathrm{~km}$. Since the beginning of the last century, the Gulf of Suez has been a highly attractive hydrocarbon location and the focus of much oil exploration. The Miocene successions in the Gulf of Suez display radical vertical and lateral facies changes due to its tectonic rift events. Gulf of Suez tectonic setting played an important role in facies distribution, configuration of the depositional sequences and resulted in the initiation of many palaeo-highs during most of the Miocene age (Evans and Moxon, 1986). Microfaunal zonation and paleoecologic interpretation of the Gulf of Suez area were attempted before (Macfadyen, 1931; Souaya, 1966; El-Heiny and Martini 1981; Andrawis and Abdel Malik, 1981; Evans, 1988; Haggag., et al 1990; El-Azabi 2004; Abul-Nasr et al., 2009; Mandur, 2009; Mandur and Baioumi, 2011; Hewaidy et al. 2013,2016 and Ayyad., et al 2018). The aim of the present work is to apply the results of analyses of planktic foraminiferal and calcareous nannoplankton assemblages to construct lower-middle Miocene integrated biostratigraphic schemes and a high-resolution correlation for the LowerMiddle Miocene succession in Ras El Ush Oil Field at Gebel Zeit area.

\section{LITHOSTRATIGRAPHY}

Lithostratigraphically, the Miocene successions in the Gulf of Suez area have been studied and classified by many authors (e.g. Moon and Sadek 1923, 1925; Ghorab \& Marzouk (1967), Said \& El Heiny (1967), the National Stratigraphic Sub-Committee (1976), Grafunkel \& Bartov (1977), El Heiny (1982), El-Azabi, (2004), Ied et al.(2011),Soliman et al.,(2012),Hewaidy et al.,(2013), and Hewaidy et al., (2016). According to the National 


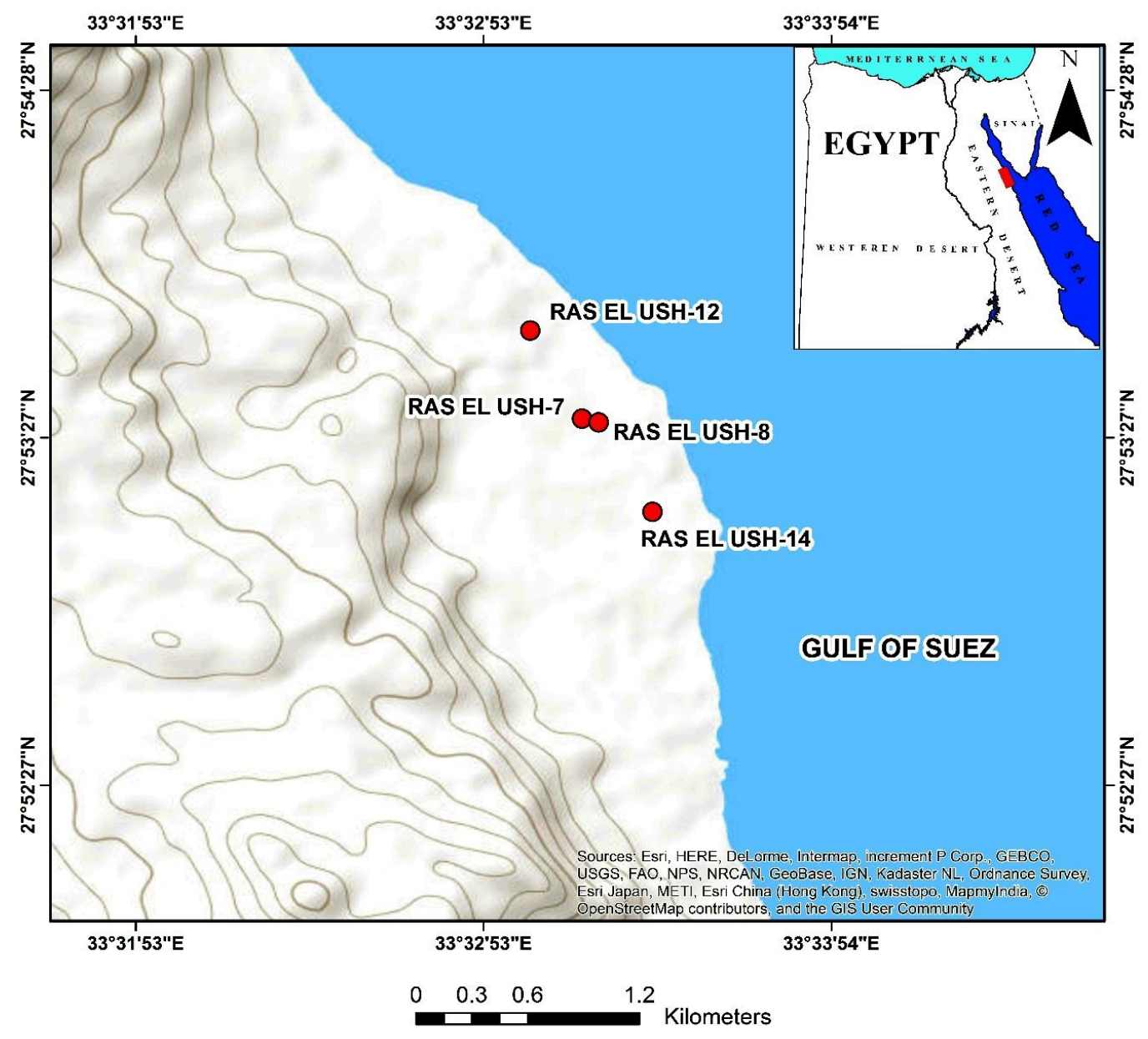

Fig.1. Location map of the studied wells at Ras Elush Oil Field, Gebel Zeit area (Conoco, 1987 and Issawi et al., 1999)

Stratigraphic Sub-Committee, (1976), The Miocene sequence in the Gulf of Suez is classified into two major lithostrtigraphic units. from older to younger as follows

1. The lower mainly clastic Gharandal Group, subdivided into the Nukhul, Rudeis and Kareem formations from base to top.

2. The upper Ras Malaab Group, subdivided into the Belayim, South Gharib, and Zeit formations from base to top.

In the present study, the Rudeis, Kareem and Belayim formations are examined and described in detail.

\section{Rudeis Formation}

Ghorab (1964) firstly introduced the term ' Rudeis Formation' at its type section (Rudeis-2 well) in west central Sinai. The Rudeis Formation is formally approved by the National Stratigraphic Subcommittee of the Geological Sciences of Egypt (NSSGS), 1974.

The Rudeis Formation overlies unconformably the Nukhul Formation and underlies unconformably the Kareem Formation at Ras El Ush 8, Ras El Ush 12 and Ras El Ush 14, while at Ras El Ush 7 it unconformably underlies the Belayim Formation due to the tectonic event. The Rudeis Formation is widely distributed and well developed on both sides of the Gulf of Suez region. It is separated by the mid-Clysmic event (Garfunkel and Bartov, 1977; Hewaidy et al., 2013; Hewaidy et al., 2016). It is composed of white and offwhite, cryptocrystalline, argillaceous limestone. A major lateral 
thickness variation of Rudeis Formation is noticed. 2095 feet (between 2960 to 865 feet) at Ras El Ush 7 well; 2011 feet from (2749 to 738 feet) at Ras El Ush 8 well; 16951 feet (from 2705 to 1010 feet) at Ras El Ush 12 well and in Ras El Ush 14 well it attains about 2667 feet thick (from 3360 to 693 feet).

\section{Kareem Formation}

Moon and Sadek (1923) firstly introduced the term ' Kareem Formation 'at its type section (Gharib North-2 Well). The Kareem Formation is formally approved by the National Stratigraphic Subcommittee of the Geological Sciences of Egypt (NSSGS), 1974. This unit is well represented in the central part of the Gulf of Suez basin where it was deposited in a structurally deep faulted area.

The Kareem Formation is of middle Miocene (Langhian) age. It unconformably overlies the Rudeis Formation and represents the oldest extensive evaporites development in the Gulf of Suez. In the present study, it is recorded in Ras El Ush 8, Ras El Ush 12 and Ras El Ush14 wells unconformably overlying the Rudeis Formation, while it is missing in Ras El Ush 7 well due to tectonic activity. It consists mainly of calcareous shales and argillaceous limestones with few anhydrites at the base. The thickness of this formation differs from place to another. In the Ras El Ush 8 well the Kareem Formation occupies the depth from 738 to 524 feet with a total thickness of about 214 feet, In the Ras El Ush 12 well it occupies the depth from 1010 to 750 feet with a total thickness of about 260 feet while at Ras El Ush 12 well, the thickness of this formation is about 174 feet from depth 693 to 519 feet.

\section{Belayim Formation}

Ghorab, (1964) firstly introduced the Belayim Formation at its type locality at the Belayim Oil Field, Gulf of Suez. The Belayim Formation is formally approved by the National Stratigraphic Subcommittee of the Geological Sciences of Egypt (NSSGS), 1974.
The Belayim Formation is of the middle Miocene (Serravalian) age. It unconformably overlies the Kareem or Rudeis formations respectively and underlies South Gharib or Zeit formations due to tectonic activity. It consists mainly of anhydrites, argillaceous limestones and calcareous shales.

\section{MATERIAL AND METHODS}

\subsection{Sample preparation}

Sixty ditch-cutting samples from four offshore wells penetrated in the Ras El Ush Oil Field, east G. Zeit. Ras El Ush-7, 8, 12 and 14 wells are prepared for foraminiferal and calcareous nannofossil contents. The obtained residues were dried, packed, and studied under Binocular Olympus Stereoscopic Microscope. The calcareous nannofossils were separated from the studied samples and identified by using Olympus Polarizing Microscope with $\times 100$ oil immersion lens.

The biostratigraphic schemes adopted here are those of Wade et al. (2011), Martini, 1971 and Perch-Nielsen, 1985.

\subsection{Faunal pattern}

One hundred and fifty-one foraminiferal species, of which 47 are planktics, 104 are benthics, in addition to 45 calcareous nannoplankton species, are identified and their first occurrence $(=\mathrm{FO})$ and last occurrence (=LO) events are recorded. The SEM photographs of important species were taken and shown on plate 1 for the planktic foraminiferal species and plate 2 for the nannofossil species. The planktic foraminifera and nannoplankton assemblages in the Burdigalian-Serravallian sediments from Ras El Ush wells are moderate to well preserved.

\section{BIOSTRATIGRAPHY}

Planktic foraminifera and calcareous nannoplankton fauna were used for providing good resolution of biostratigraphic biozonation. The age determination for the study area is based on these fossil groups. Furthermore, the significant bioevents between planktic 
foraminifera and calcareous nannoplankton are discussed too.

\subsection{Planktic foraminiferal biozones}

The biostratigraphic scheme of Wade et al. (2011) is used here. Three planktic foraminiferal biozones were determined in ascending stratigraphic order. The distribution of planktic foraminifera are shown on Figs.3, 4, 5 and 6.

\subsubsection{Catapsydrax dissimilis Concurrent Range Zone (M3)}

Definition: Wade et al. (2011) defined this zone as the concurrent range of the nominate taxa between the LO of Globigerinatella sp. and the $\mathrm{HO}$ of Catapsydrax dissimilis. The Globigerinatella species is not recorded in the studied successions. In the present study, this zone is defined as the biostratigraphic interval of the nominate taxon (the HO of Catapsydrax dissimilis).

Author: Bolli, 1957; emended by Blow, 1969; Berggren et al. (1995) and Wade et al. (2011).
Age: early Miocene (Burdigalian); 19.66-17.62 Ma.

Assemblage: Species of the genus Globigerinoides are the most common taxa in this zone. These are Globigerinoides altiaperturus Bolli, Gs. immaturus (Le Roy), Gs. quadrilobatus (d'Orbigny), Gs. sacculifer Brady and Gs. trilobus (Reuss). The following species are common too: Globorotalia mayeri Cushman \& Ellisor, Gt. munda Jenkins, Gt. semivera (Hornibrook), Cassigerinella chipolensis (Cushman \& Ponton), Gg. Globigerina angustiumbilicata (Bolli) Gg. preabulloides (Bolli), Gg. leroyi (Bolli), Gg. occlusa (Bolli), Gg. bulloides d'Orbigny, Gg. falconensis Blow, Globigerinella obesa (Bolli), (figs.2,3,4 and 5).

Occurrence: This zone is represented by the lower part of the Rudeis Formation in all the studied wells (figs.2, 3, 4 and 5). It varies in thickness from well to the other. It attains a thickness of about 1140 feet at Ras El Ush 7, 700 feet at Ras El Ush 8, 290 feet at Ras El

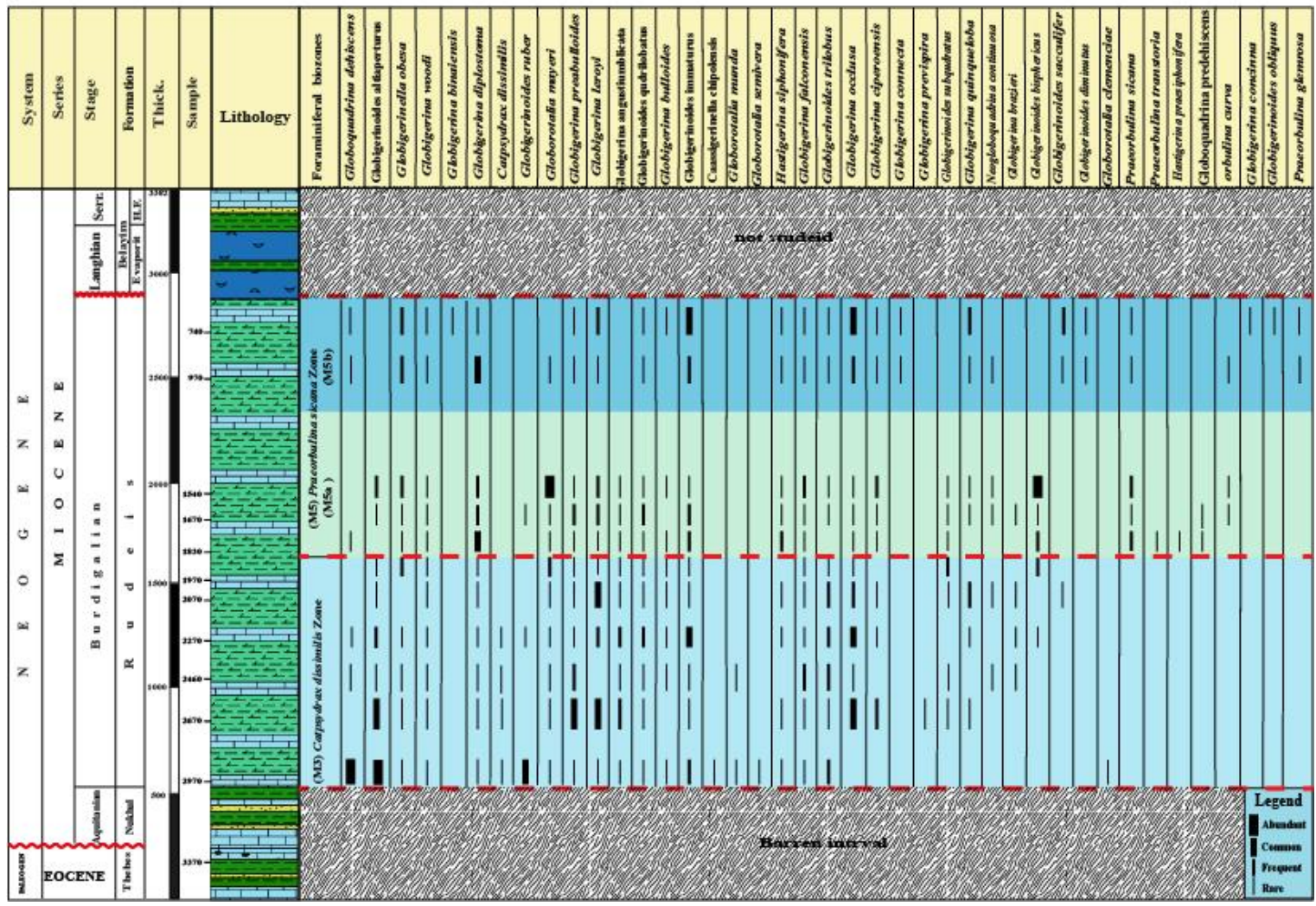

Fig.2. Distribution chart of the planktic foraminiferal species recorded at Ras EI Ush 7 section 
Ush12, whereas at Ras El Ush 14 it is about 1300 feet. The distribution of planktic foraminifera is plotted on Figs.2, 3, 4 and 5.

Remarks: This zone has been established initially by Blow $(1969,1979)$. However, The LAD of Catapsydrax sp. represents a distinct bioevent which have been occurred in transitional and high-latitude areas as well and serves as a point of regional correlation in the late early Miocene (Berggren et al., 1995). It is equivalent to the Globigerinoides altiaperturus (M3) Zone of Bolli (1957). The most characteristic feature of this zone is that the genus Globigerinoides becomes more common and represented by different species (Figs.2, 3, 4 and 5). The M4 Zone is not recorded in the present study due to the "mid-Clysmic" or "mid-Rudeis" event during which basin asymmetries in the rift basin were formed (Patton et al. 1994).

\subsubsection{Praeorbulina sicana Interval Zone (M5)}

Definition: Initially, this zone is defined as the biostratigraphic interval between the LO of Praeorbulina sicana and the LO of Orbulina suturalis.

Author: Blow, 1969, 1979.

Age: Early to middle Miocene (BurdigalianLanghian); 16.40-15.10 Ma.

Assemblage:M5 Zone is characterized by the co-occurrence of the planktic foraminiferal species: Globigerina bulloides d'Orbigny, Globigerina praebulloides Blow, Globigerinella obesa Bolli, Globigerina concinna Reuss, Globigerinoides immaturus Le Roy, Globigerinoides quadrilobatus d'Orbigny, Globigerinoides bisphericus Todd \& Post, Globigerinoides sacculifer Brady, Praeorbulina sicanus De Stefani, Praeorbulina glomerosa (Blow), Praeorbulina transtoria, Preaorbulina curva Blow and Globigerinoides trilobus Reuss.

Occurrence: This zone is recorded in the uppermost part of the Rudeis Formation at Ras
El Ush 7 and Ras El Ush 14, whereas it is represented by the top part of the Rudeis Formation and the lower part of the Kareem Formation at Ras El Ush 8 and Ras El Ush 12. It attains a thickness of about 1090 feet at Ras El Ush7, 800 feet at Ras El Ush 8,590 feet at Ras El Ush 12 and 690 feet at Ras El Ush 14. It is distinguished by high diversity with moderately preserved planktic foraminiferal assemblage (figs.2, 3, 4 and 5).

Remarks: According to Iaccarino (1985), this zone is defined as the interval from the FO of $P$. sicana De Stefani to the LO of P. glomerosa (Blow). The evolutionary transition from Praeorbulina to Orbulina took place during this zone (Berggren et al. 1995). It is approximately equivalent in stratigraphic level to the Praeorbulina glomerosa Zone of Bolli (1957, 1966), Bolli and Bermudez (1965), Stainforth et al. (1975), Postuma (1971), Globorotalia peripheroronda Zone of Bolli and Saunders (1985) and Praeorbulina glomerosa of Iaccarino (1985). In Egypt, this zone corresponds to the Praeorbulina glomerosa Zone of Kerdany (1967) in the Gulf of Suez, and (Farouk et al., 2014) in the Nile Delta. This zone can be correlated with the lower part of the Globigerinoides sicanus / Globigerinoides transitoria of Wasfi (1968), Globigerinoides sicanus of Beckmann et al., 1986 and Praeorbulina sicanus /Orbulina suturalis Zone (M5) of (Hewaidy et al., 2013 and 2016). Berggren et al. (1995) classified the M5 Globigerinoides sicanus -Orbulina suturalis Zone into two subzones Praeorbulina sicana (M5a) and Praeorbulina glomerosa (M5b).

\subsection{2a: M5a Subzone (Praeorbulina sicana Interval Subzone)}

Definition: Biostratigraphic interval between the HO of Praeorbulina sicana and the LO of Praeorbulina glomerosa.

Age: early Miocene (Burdigalian); 16.38-16.27 Ma. 


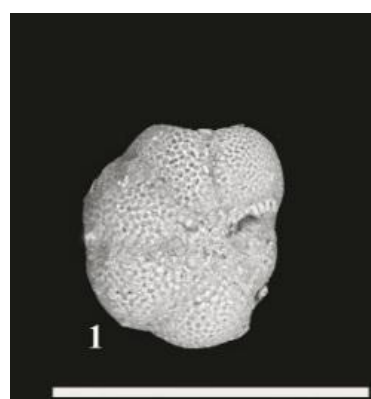

$400 \mathrm{mu}$

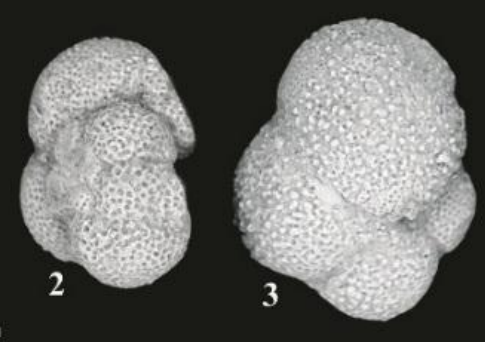

$300 \mathrm{mu}$

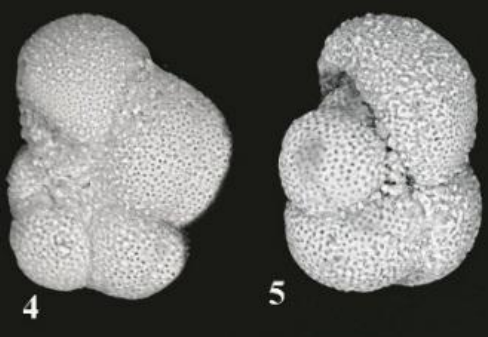

$300 \mathrm{mu}$

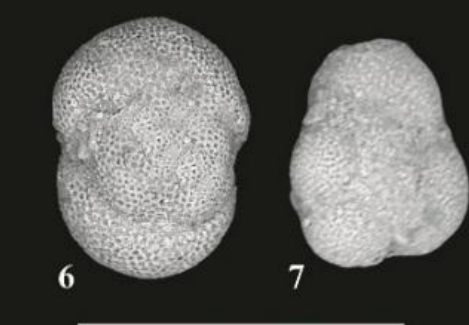

$400 \mathrm{mu}$

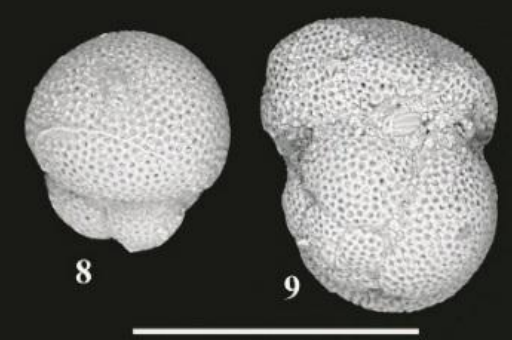

$400 \mathrm{mu}$

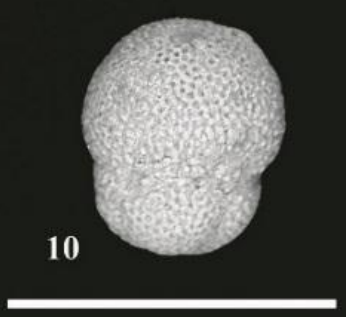

$500 \mathrm{mu}$
13

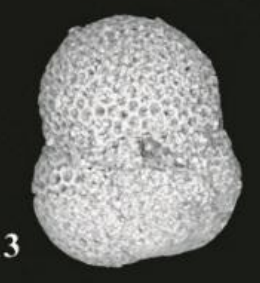

14

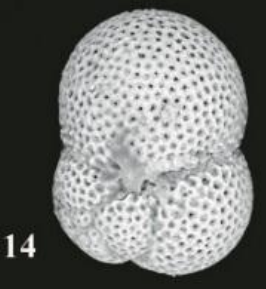

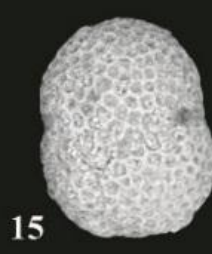

15

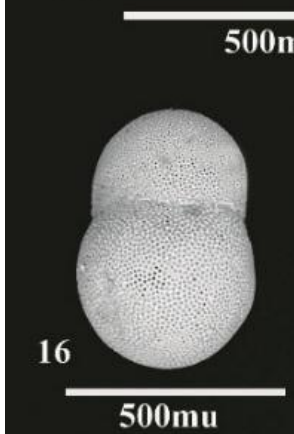

$00 \mathrm{mu}$
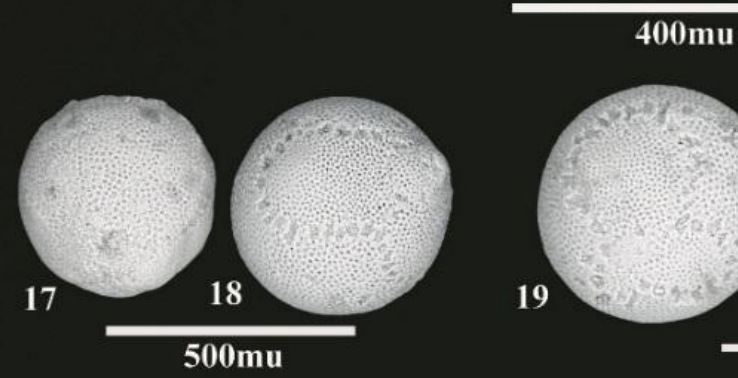

$400 \mathrm{mu}$

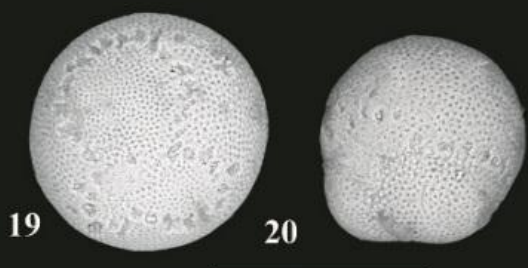

$400 \mathrm{mu}$
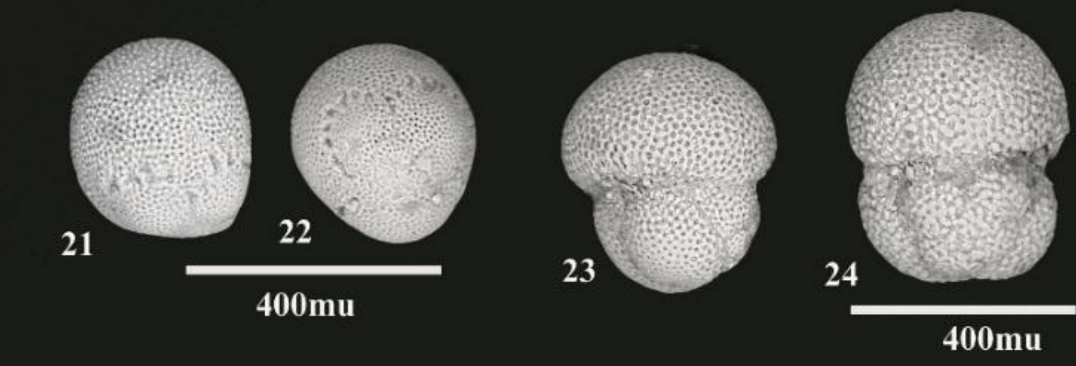

25

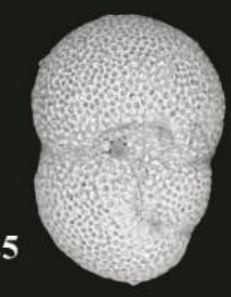

Plate1. 1. Fohsella peripheroacuta Blow and Banner, 2-3. Globorotalia scitula Brady, 4-5. Neogloboquadrina continuosa Blow, 6-7. Catapsydrax dissimilis Cushman and Bermudez, 8-9. Globigerina binaiensis Koch, 9-11. Globigerinoides bisphericus, Todd \& Post, 12-14. Globigerinoides diminutus; Bolli, 15. Orbulina bilobata d'Orbigny, 16-17. Orbulina suturalis Brönnimann, 18-19. Preaorbulina glomerosa, Blow, 20-21. Preaorbulina curva; Blow, 22. Preaorbulina circularis Blow, 23-24. Preaorbulina sicana, De Stefani, 25. Preaorbulina transitoria, Blow. 

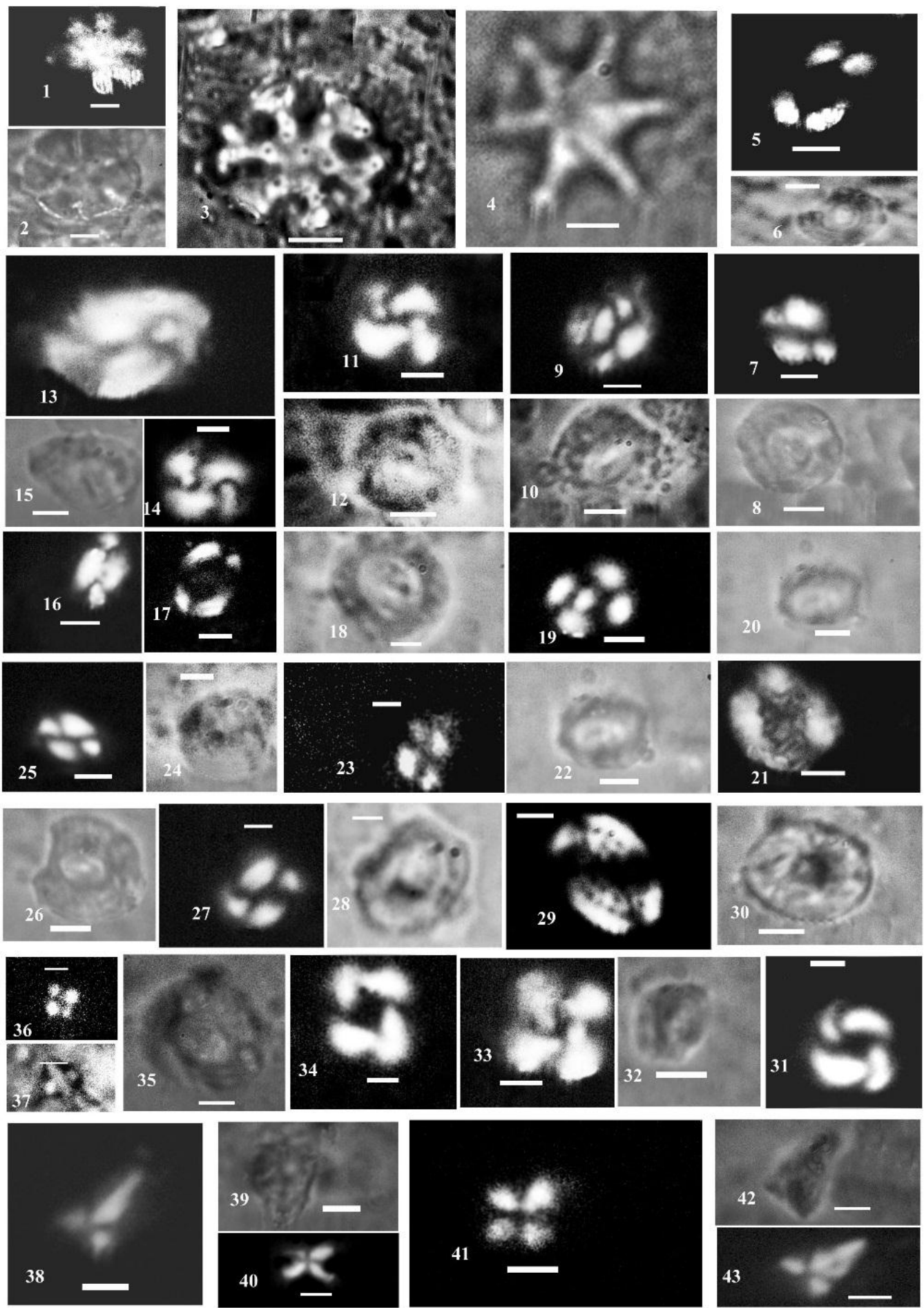

Plate 2. 1-3. Discoaster deflandrei Bramlette and Riedel, 4. Discoaster exilis Martini and Bramlette, 5-6. Helicosphaera ampliaperta Bramlette \& Wilcoxon, 7-8. Helicosphaera carteri Wallich, 9-10. Helicosphaera compacta Bramlette \& Wilcoxon, 11-12 Helicosphaera euphratis Haq, 13. Helicosphaera gertae Bukry, 14-15. Helicosphaera intermedia Martini, 16. Helicopontosphaera kamptneri Hay \& Mohler, 17-18. Helicosphaera mediterranea Müller, 19-20. Helicosphaera obliqua Bramlette \& Wilcoxon, 21-22. Helicosphaera reticulata Bramlette \& Wilcoxon, 23-24. Helicopontosphaera rhomba Bukry, 25-26. Helicosphaera scissura Miller, 27-28. Helicosphaera vedderi Bukry, 29. Pontosphaera multipora Kamptner, 31-32. Reticulofenestra haqii Backman, 33. Reticulofenestra perplexa Burns, 34-35. Reticulofenestra pseudoumbilica Gartner, 36-37. Sphenolithus compactus Backman, 38-40. Sphenolithus belemnos Bramlette \& Wilcoxon, 41-42-43. Sphenolithus heteromorphus Deflandre 
Remarks: This subzone is strongly matched with the upper part of the Globigerinatella insueta Zone of Cushman and Stainforth (1945; as emended in Bolli, 1957b) and to the lower part of Zone N8 of Blow (1969, 1979). It was renamed according to the convention of Berggren and Pearson (2005).

\subsection{2b: M5b Subzone (Praeorbulina glomerosa Interval Subzone)}

Definition: Biostratigraphic interval between the LO of Praeorbulina glomerosa and the LO of Orbulina suturalis.

Age: early-middle Miocene (Langhian);16.2715.10 Ma.

Remarks: This subzone coincides tightly, but not accurately, with the Praeorbulina glomerosa Zone of Jenkins (1967) and Kennett and Srinivasan $(1981,1983)$ in which the FAD of Pr. glomerosa curva was used to indicate the base of the zone. It also coincides with the upper part of Zone N8 of Blow (1969, 1979). The zone of M6 was not recorded in the present study due to tectonic activity.

\subsubsection{Barren interval}

The lower part of the Belayim Formation is barren of the planktic foraminifera and calcareous nannoplankton in all the studied wells (figs.2, 3, 4 and 5).

\subsubsection{Fohsella peripheroacuta Interval Zone (M7).}

Definition: Biostratigraphic interval between the LO of the nominate taxon Fohsella peripheroacuta and the LO of Fohsella praefohsi.

Authors: Berggren et al., (1995).

Age: middle Miocene; 14.24-13.77 Ma.

Assemblage: This zone is characterized by the common presence of Globoquadrina dehiscens Chapman, Globigerinoides obliquus Bolli, Globigerinoides subquadratus Brönnimann, Globorotalia mayeri (Cushman \& Ellisor), Orbulina bilobata (d'Orbigny), Orbulina suturalis (Brönnimann), Globigerinoides sacculifer (Brady), Praeorbulina sicana (Di Stefani) and Praeorbulina glomerosa (Blow).

Occurrence: It is recorded in the upper part of the Belayim Formation at Ras El Ush 8 borehole (Fig. 3). It attains a thickness of about 400 feet. While it is barren in both planktonic foraminifera and calcareous nannoplankton in other boreholes

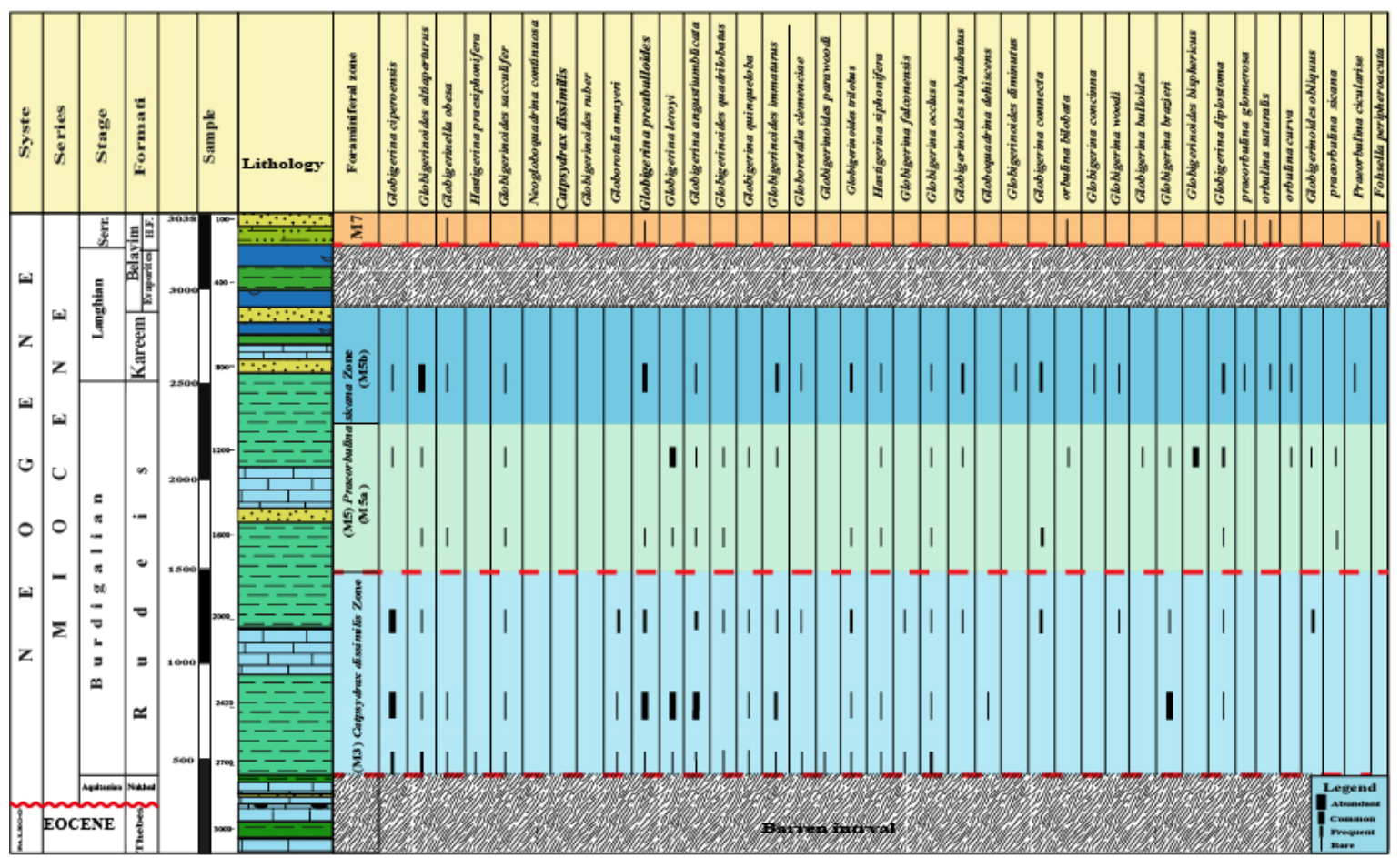

Fig.3. Distribution chart of the planktic foraminiferal species recorded at Ras EI Ush 8 




Fig.4. Distribution chart of the planktic foraminiferal species recorded at Ras EI Ush 12 section

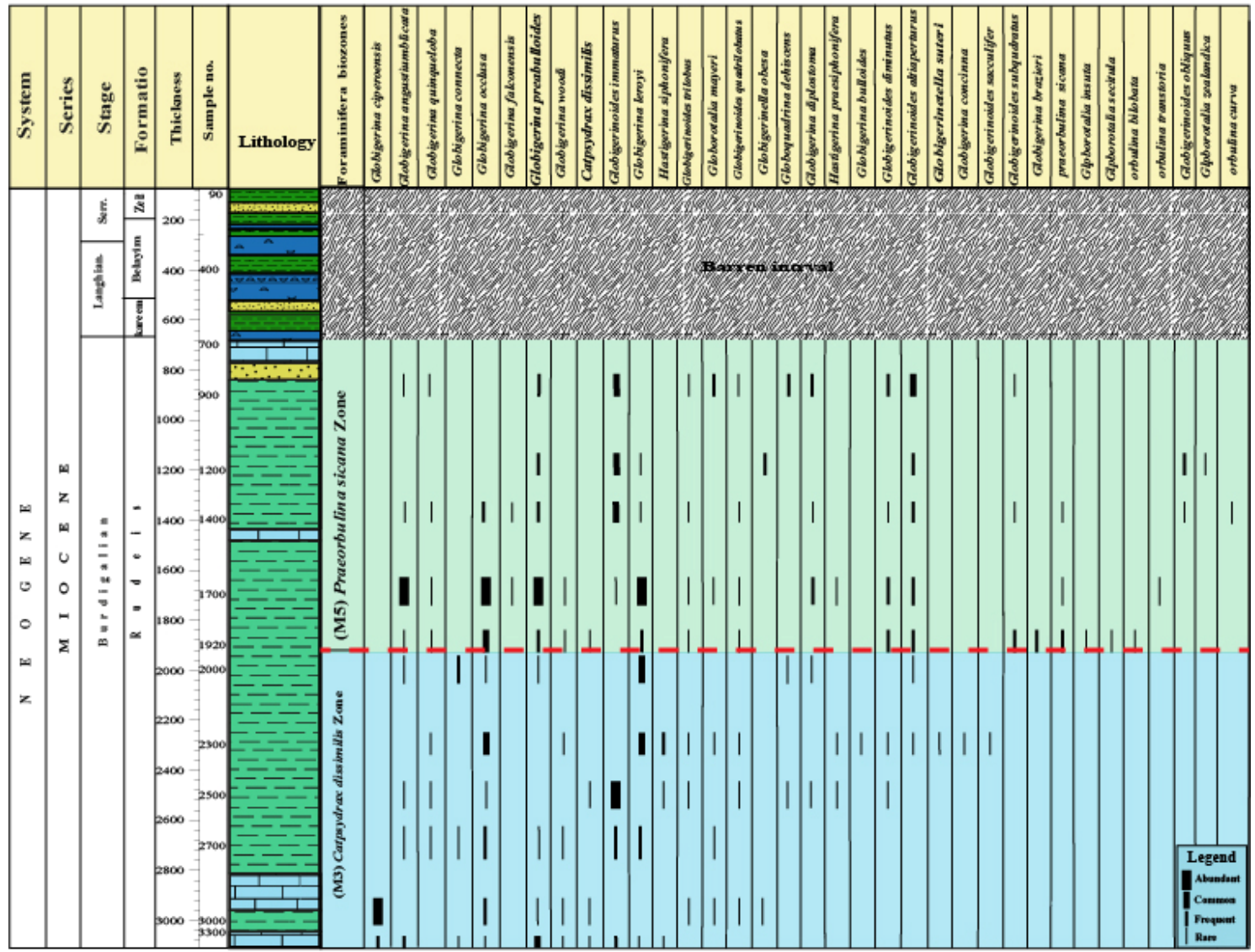

Fig.5. Distribution chart of the planktic foraminiferal species recorded at Ras EI Ush 14 section 
Remarks: This zone corresponds to Orbulina suturalis / Globorotalia peripheroronda Zone of Iaccarino (1985) and Fohsella peripheroacuta Zone of Berggren et al., (1995). In the Mediterranean Sea, Kennett and
Srinivasan (1983) recorded Globorotalia siakensis Zone (N15) which coincides with this zone. Biostratigraphical correlation of the Early- Middle Miocene foraminiferal biozones are summarized in (Fig.6).

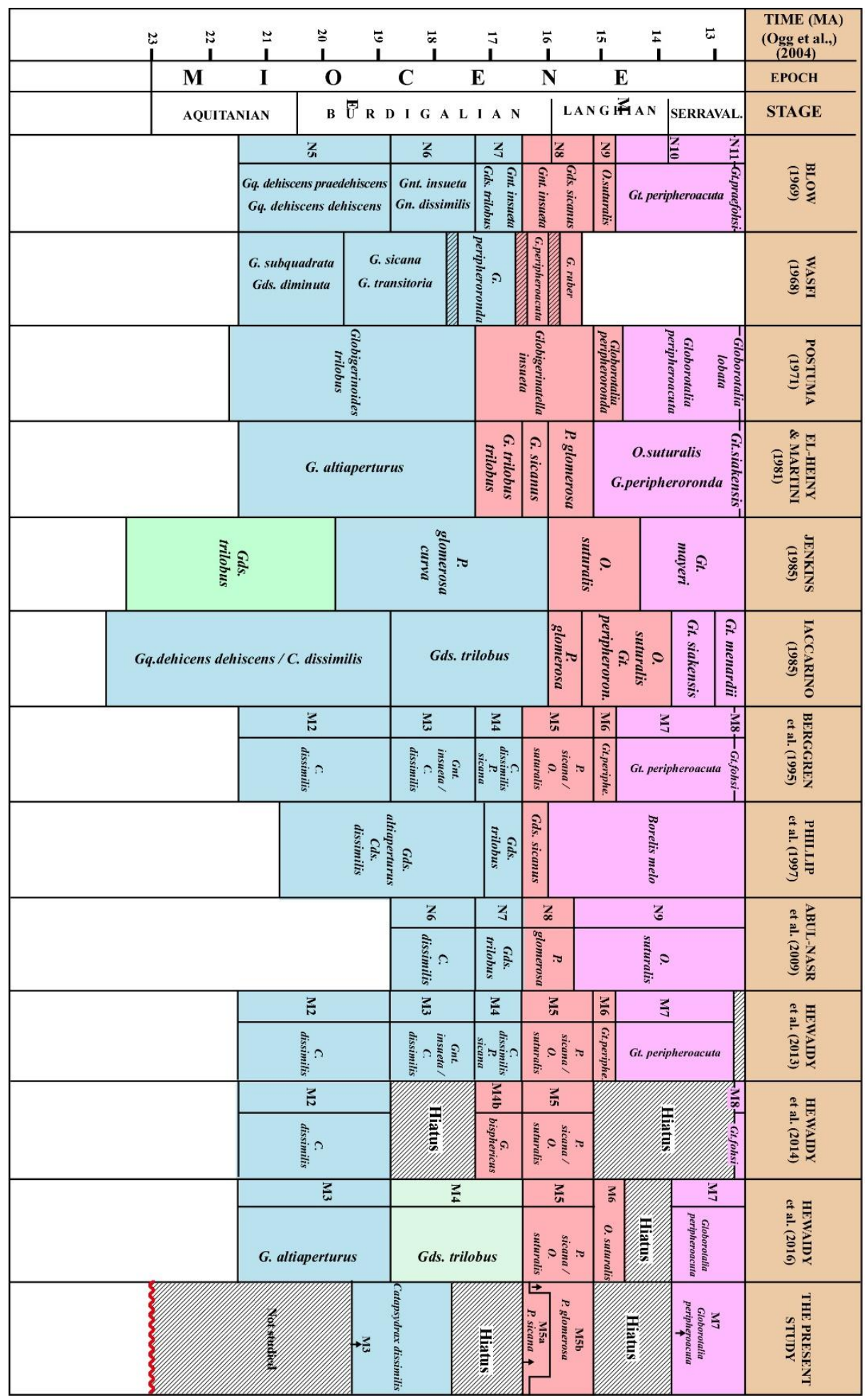

Fig.6. Planktic foraminiferal biozones used by different authors for the Early Miocene (Aquitanian) - middle Miocene (Serravallian). 


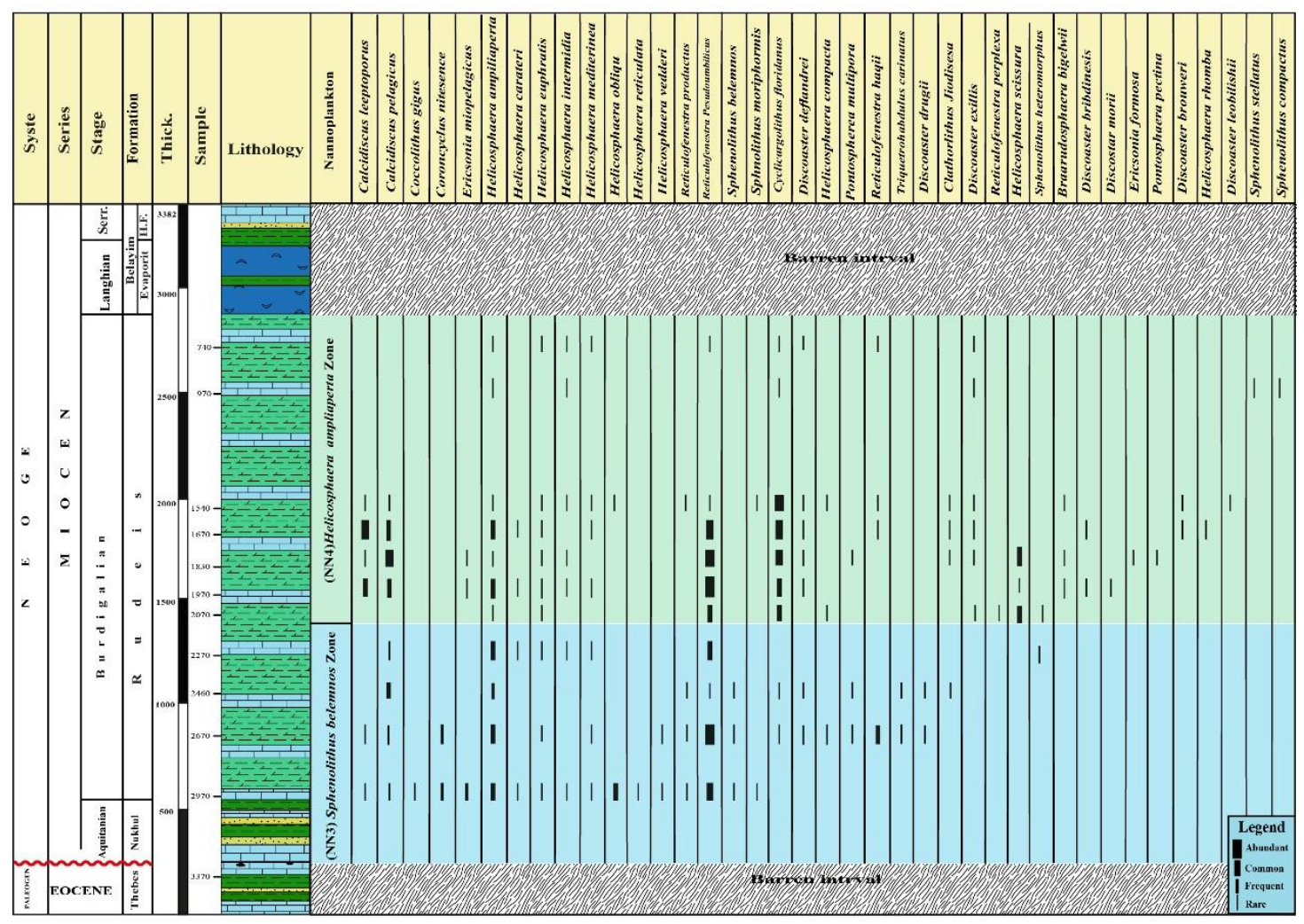

Fig.7. Distribution chart of the nannoplankton species recorded in Ras El Ush 7 section.

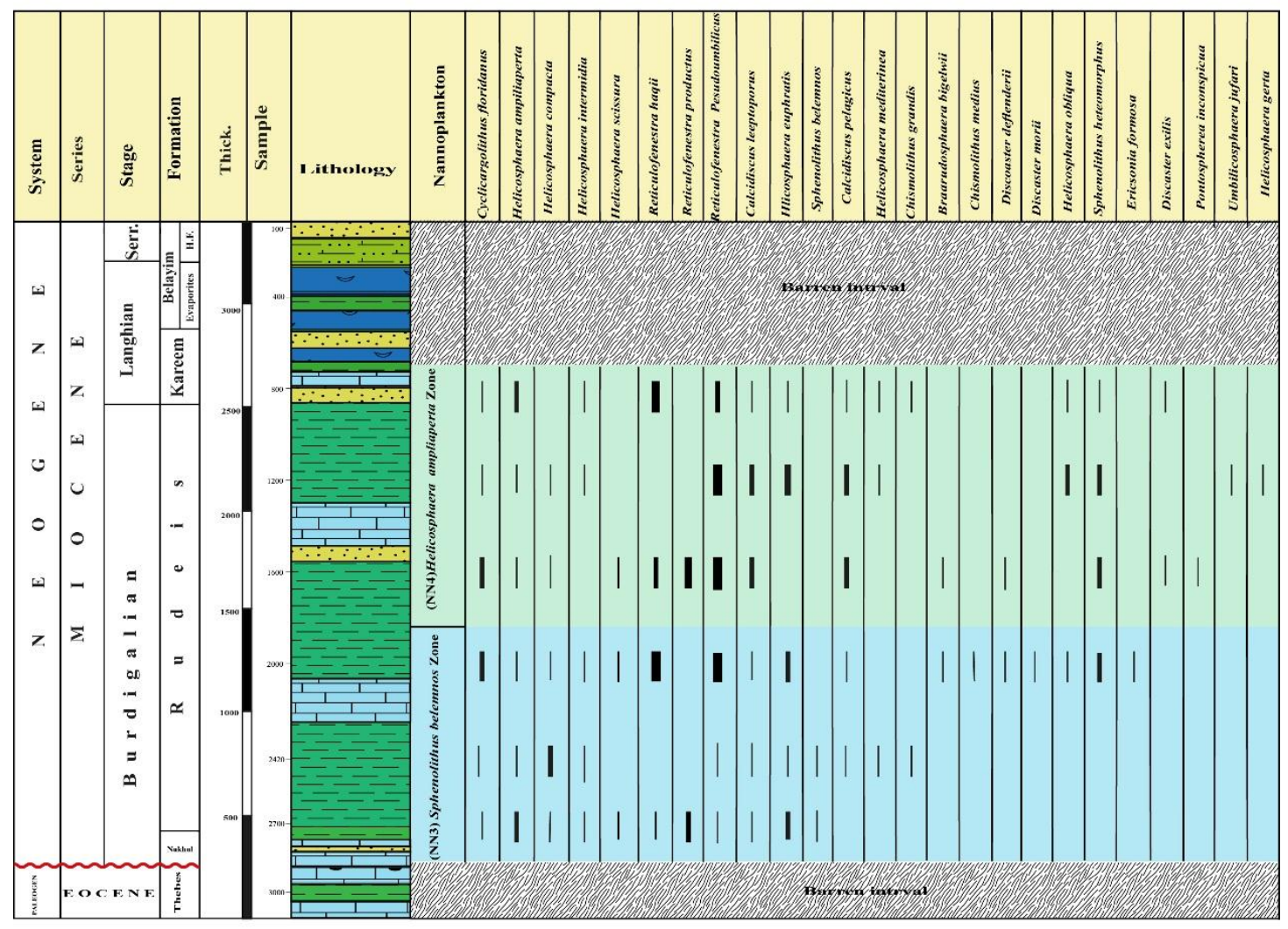

Fig.8. Distribution chart of the nannoplankton species recorded at Ras El Ush 8 section 


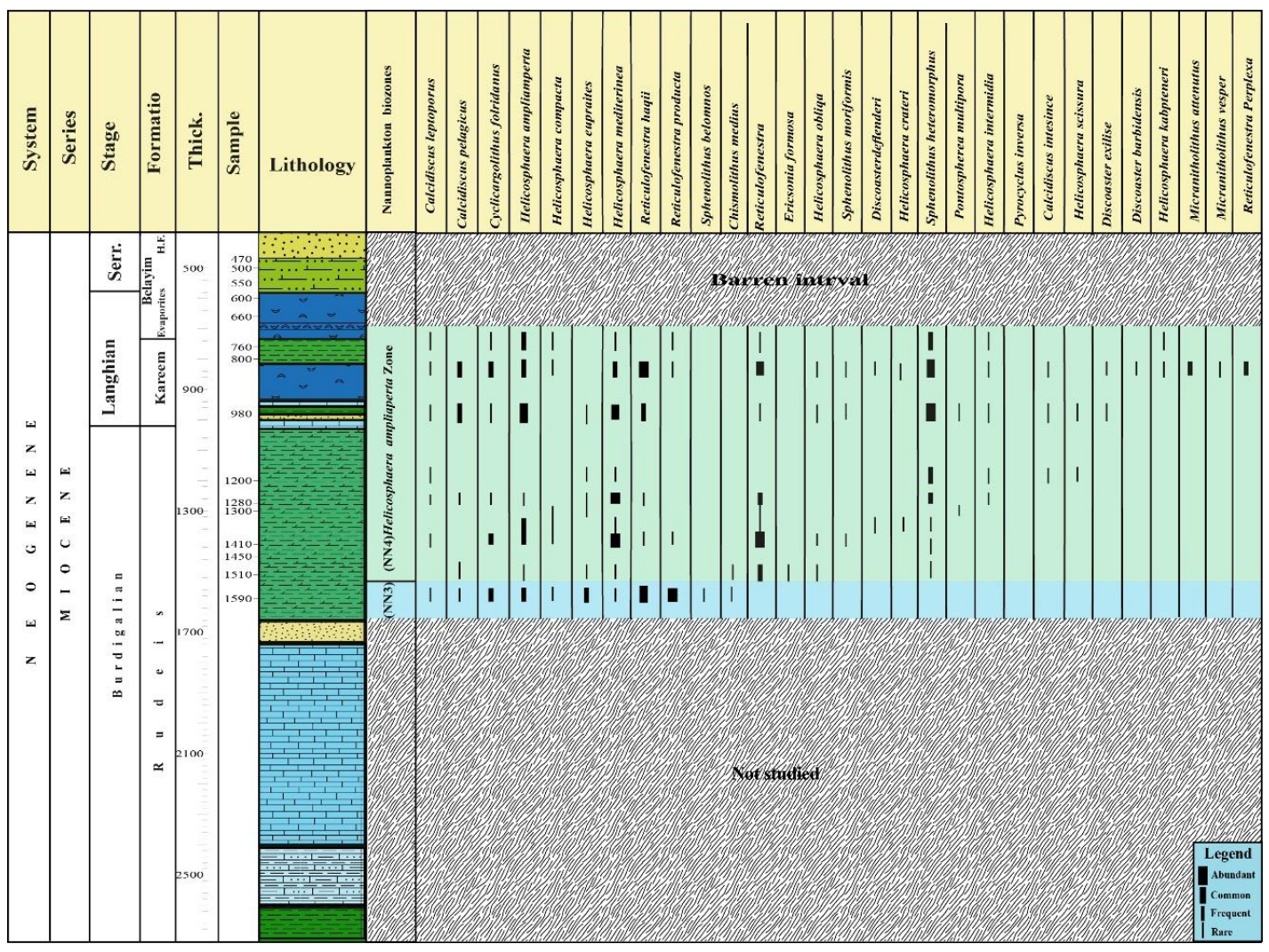

Fig.9. Distribution chart of the nannoplankton species recorded at Ras EI Ush 8 section.

\section{Calcareous nannofossil biozones}

The calcareous nannofossils are a primary fossil group used in the biostratigraphic classification for their great abundance, rapid rate of evolution and planktic nature that allows a full dispersal throughout the world oceans (Mandur, 2015). 45 calcareous nannoplankton species in the studied sections belonging to 13 genera are identified and shown in distribution charts (Fig.7, 8, 9 and 10). The most important calcareous nannoplankton species are shown on plate (2). In the present study, two calcareous nannoplankton biozones recognized in the studied four boreholes and following the nannoplankton zonal scheme presented in Martini, 1971and Perch- Nielsen, 1985.

These biozones are discussed here, from base to top as follows.

\subsubsection{Sphenolithus belemnos Zone (NN3)}

Definition: It is defined from LO of Triquetrorhabdulus carinatus to the LO of Sphenolithus belemnos (Bramlette and Wilcoxon1967) and (Martini, 1971). In the present study, it is distinguished by the common and continuous presence of Sphenolithus belemnos.

Authors: Bramlette \& Wilcoxon, 1967, emended by Martini, 1971.

Age: Early Miocene (Burdigalian); 18.28 to 17.95 Ma.

Assemblage: the following well preserved and dominant species are recorded in this zone:

Sphenolithus belemnos Bramlette and Wilcoxon, S. moriformis Bronnimann and Stradner,

Helicosphaera carteri Kamptner, $H$. intermedia Martini, $H$. mediterranea Muller, $H$. scissura Miller, Pontosphaera multipora (Kamptner), Braarudosphaera beglowii (Gran and Braarud), Ericsonia robusta (Bramlette and Sullivan), Ericsonia formosa Black, Discoaster deflandrei Bramlette and Riedel, and Cyclicargolithus floridanus Bukry.

Stratigraphic position: It is recorded in the Rudeis Formation at the four studied wells. It attains a thickness of about 900 feet at Ras El Ush7, 700 feet at Ras El Ush 8,80 feet at Ras El Ush 12 and 1000 feet at Ras El Ush 14 (figs.7, 8,9 and 10). 


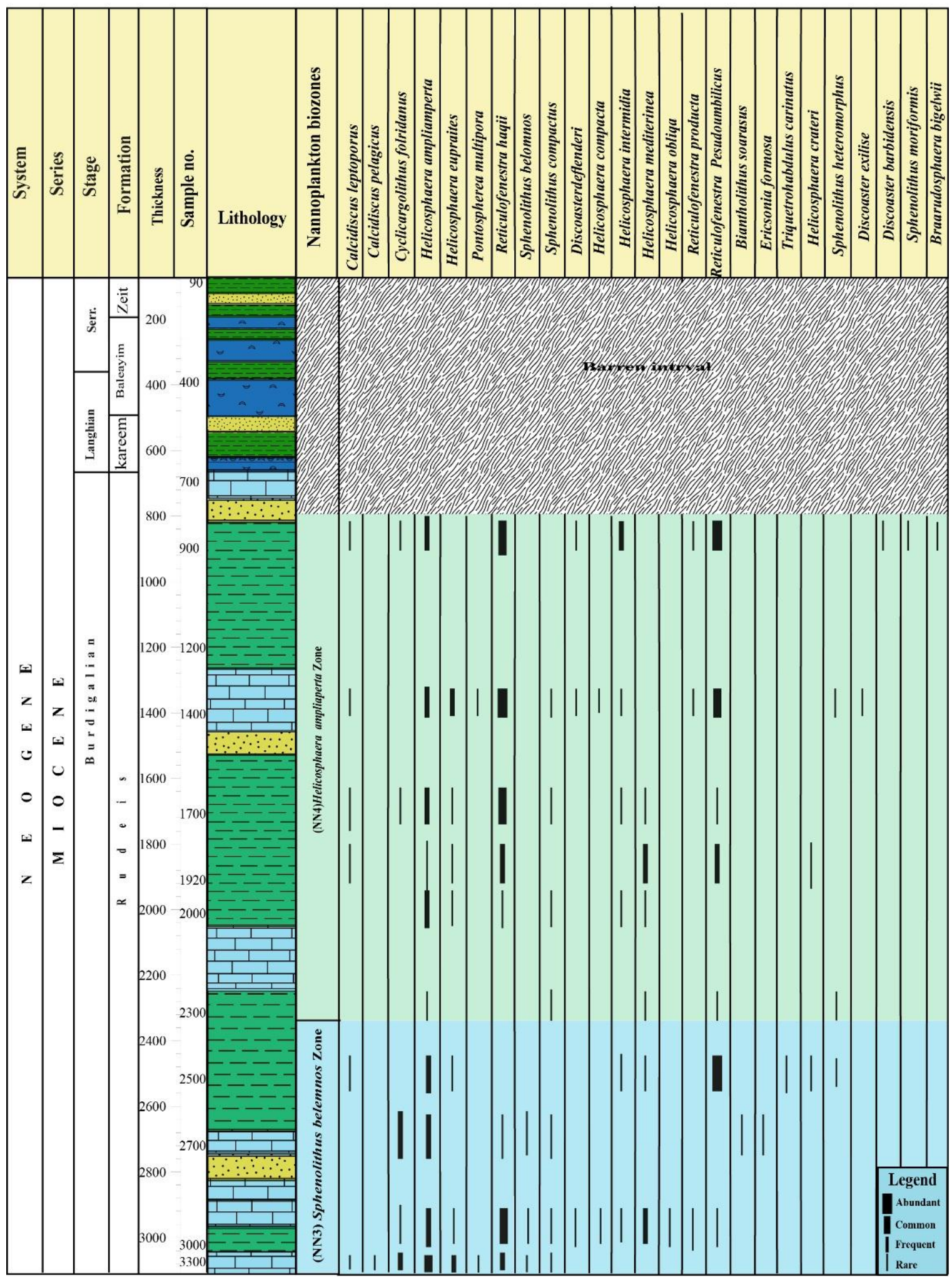

Fig.10. Distribution chart of the nannoplankton species recorded at Ras EI Ush 8 section 
Remarks: This zone is equivalent to Sphenolithus belemnos NN3 Zone of Bramlette \& Wilcoxon, (1967), Bukry (1973), Backman et al., 2012 and Holcovkà, (2013). It corresponds to Discoaster deflandrei Zone of Kerdany, (1967) and Sphenolithus belemnos Zone of El-Heiny and Martini (1981), Marzouk (1998, 2009), Mandur (2004 and 2009 and Faris et al., (2007 and 2009).

\subsubsection{Helicosphaera ampliaperta Zone (NN4)}

Definition: It is represented by the interval from the HO of Sphenolithus belemnos to $\mathrm{HO}$ of Helicosphaera ampliaperta Martini, 1971. In the present study it is characterized by a biostratigraphic interval of LO of Sphenolithus heteromorphus with presence of Helicosphaera ampliaperta above the $\mathrm{HO}$ of Sphenolithus belemnos.

Authors: Bramlette \& Wilcoxon, 1967; emended by Martini, 1971.

Age: Early Miocene (Burdigalian) to Middle Miocene (Langhian); 17.95-14.91 Ma.

Assemblage: the following well preserved and dominant species are recorded in this zone: Sphenolithus belemnos Bramlette and Wilcoxon, S. moriformis Bronnimann and Stradner, Helicosphaera carteri Kamptner, $H$. intermedia Martini, $H$. mediterranea Muller, $H$. scissura Miller, Pontosphaera multipora (Kamptner),Braarudosphaera beglowii (Gran and Braarud ), Ericsonia robusta (Bramlette and Sullivan), Ericsonia formosa Black, Discoaster deflandrei Bramlette and Riedel, and Cyclicargolithus floridanus Bukry. (Figs.7, $8,9$ and 10$)$.

Stratigraphic position: This zone has been recorded in the upper part of the Rudeis Formation and Kareem Formation in all wells. It attains a thickness of about 1330 feet at Ras El Ush7, 1200 feet at Ras El Ush 8,750 feet at Ras El Ush 12 and 1400 feet at Ras El Ush 14.

Remarks: This zone is equivalent to $H$. ampliaperta NN4 Zone of Bramlette \& Wilcoxon (1967), Martini (1971), Backman et al., 2012 and Holcovkà (2013). In the present study, the $H$. ampliaperta Bramlette and Wilcoxon is abundant in the four studied boreholes when Sphenolithus belemnos is disappearing. So, it is considered that the LO of $H$. ampliaperta is a more likely marker event for $H$. ampliaperta Zone in the investigated subsurface sections. Previously, the LO of $H$. ampliaperta is likely marker event for $H$. ampliaperta Zone in this study. In Egypt, this zone is approximately corresponding to the Helicosphaera ampliaperta Zone of El-Heiny and Martini (1981), Marzouk (1998, 2009), Sadek (2001), Mandur (2009), Faris et al., (2007, 2009), Soliman et al., (2012) and Hewaidy et al., (2013, 2016).

\section{SUMMARY AND CONCLUSIONS}

1. Detailed biostratigraphic studies of the planktic foraminifera and calcareous nannofossils led to identification of three foraminiferal biozones (M3, M5a, M5b and M7) and two calcareous nannoplankton biozones (NN3, NN4). They are discussed in ascending stratigraphic order as follows Catpsydrax dissimilis Zone (M3) of early Miocene (Burdigalian) age, Praeorbulina sicana Zone (M5) of early-middle Miocene (Burdigalian-Langhian) age and Fohsella peripheroacuta Zone (M7) of middle Miocene (Serravallian) age, in addition to Sphenolithus belemnos Zone (NN3) of early Miocene (Burdigalian) age and Helicosphaera ampliaperta Zone (NN4) of early Miocene (Burdigalian) to middle Miocene (Serravallian) age.

2. The ranges of both planktic foraminifera and calcareous nannofossil zones proved to match reasonably with each other. These biozones were correlated with those recorded in Egypt and in other parts of the world.

3. The Burdigalian Stage is represented by one planktic foraminiferal zone M3. M4 Zone is not recorded in the present study due to Mid-Rudeis Event. M3 of planktonic foraminifera coincides with the calcareous nannofossil zones NN3 and the lower part of NN4. 
4. The base of the Langhian Stage is cited based on the FO of Orbulina suturalis near the top of Helicosphaera ampliaperta Zone.

5. The Langhian / Serravallian boundary is recognized by the FO of the planktic foraminiferal Globorotalia peripheroacuta (M7) Zone, at the Belayim Formation at Ras El Ush 8. The Serravallian Stage includes the planktic foraminiferal Fohsella peripheroacuta Zone.

6. Variable patterns in the timing of regional deposition and erosion indicate different tectonic and regime, which encompass progressively greater periods of time. There are two observable hiatuses; the first separates Zones M3and M5 and is evidenced by the absence of Zone M4. The boundary between these two rock units marks the "mid-Rudeis" or "mid-Clysmic" event as unconformity surface. On the other hand, the jump from a position within Zone M5b of the Burdigalian to a position within the lower part of Zone M7 based on the absence Zone M6 indicates a second hiatus, which resulted from the effect of the post-Kareem tectonic event.

\section{REFERENCES}

Abul-Nasr, R.A., El-Safori, Y.A., Attia, S.H., Maih A., (2009): Stratigraphy and depositional settings of the Miocene succession in the area between Wadi Sudr and Wadi Wardan, Gulf of Suez Region. Egypt. J. Paleontol. 9, 119-144.

Andrawis, S. F., \& Abdel Malik, W. M. (1981): Lower/middle Miocene boundary in the Gulf of Suez region, Egypt. Newsletters on Stratigraphy, 10, 156-163.

Ayyad, H.M., El-Sharnoby, A.A., El-Morsy, A.M., Ahmed, M.A., El-Deeb, A.A (2018): Quantitative reconstruction of paleoenvironmental conditions in the Gulf of Suez during the Burdigalian-Langhian (early to middle Miocene) using benthic foraminifera Palaeogeography, Palaeoclimatology, Palaeoecology 503,51-68

Backman J, Raffi I, Rio D, Fornaciari E, Pälike H (2012): Biozonation and biochronology of Miocene through Pleistocene calcareous nannofossils from low and middle latitudes. Newsl Stratigr 45(3): 221-244. S.

Banner FT, Blow WH (1965): Progress in the planktonic foraminiferal biostratigraphy of the neogene. Nature 208,1164-1166.
Beckmann, J.P., El Heiny, I., Kerdany, M.T., Said, R., and Viotti, C., (1986): Standard planktic zones in Egypt. First International Planktic Conference, Geneva, 92 -103.

Berggren, W.A., Kent, D.V., Swisher, C.C., and Aubry, M-P. (1995): A revised Cenozoic geochronology and chronostratigraphy. - SEPM. Pub. 54. p. 203.

Berggren, W.A, and Pearson, P. N., (2005): A revised tropical and subtropical Paleogene planktic foraminiferal zonation. Journal of Foraminiferal Research. 35, 279-298.

Bolli, H.M. (1957): Planktic foraminifera from the Oligocene - Miocene Cipero and Lengua formations of Trinidad. - Bull. U.S. Nat. Mus. 215, 83-96.

Bolli, H.M., (1966): Zonation of Cretaceous to Pliocene marine sediments based on planktonic foraminifera. Boletin Informativo Asociacio`n Venezolana de Geolog`a, Minerar`a Petroleum., Vol.9, 3 - 32 .

Bolli, H.M. 1970: The foraminifera of sites 2331, Leg 4. Initial Reports of the DSDP 4:577-643.

Bolli, H.M., and Bermudez, P.J., (1965): Consideraciones sobre los sedimentos del Mioceno medio al Reciente de las costas central y oriental de Venezuela. Bol. Geol., Dir. Geol., Minister. Minas Hidrocarb. 10, 137-223.

Bolli, H.M. and Saunders, J.B. (1985): Oligocene to Holocene low latitude planktic foraminifers. In: Plankton Stratigraphy, Eds: Bolli, H.M and Saunders, J.B.155 -262.

Blow, W.H. (1969): Late Middle Eocene to Recent planktic foraminiferal biostratigraphy. Proceedings 1st International Conf. on plank. Microfoss., Genva, (1967), 1, p. 199-442. Pls. 1-54, text-figs. 1-43.

Blow, W.H. (1979): The Cainozoic foraminiferida, vol. I and II, Leiden, E.J. Brill, 1413 p.

Bramlette MN, Wilcoxon JA 1967: Middle tertiary calcareous nannoplankton of the Cipero Section Trinnidad. Tulane Studies in Geol Paleo, 5:93-131.

Bukry, D. (1973): Low-latitude coccolith biostratigraphic zonation. - Initial Reports of the Deep-Sea Drilling Projects. 15, 685-703.

Cushman, J.A. and Stainforth, R.M. (1945): The foraminifera of the Cipero-marl Formation of Trinidad, British Indies. - Cush. Foundation, Foraminiferal Res., Sped. Publ., Sharon, Mass. no. 14, p. 1-75, Pls. 1-8. 
El-Azabi M.H. 2004: Facies characteristic depositional styles and evolution of the syn-rift Miocene sequences in the Nukhul- Feiran area, Sinai side of the Gulf of Suez Rift Basin, Egypt. Sed. Egypt 12, 69-103.

El Heiny I. 1982: Neogene stratigraphy of Egypt. Newslett. Stratigr. 1, 41-54.

El-Heiny, I. and Martini, E. (1981): Miocene foraminiferal and calcareous nanno-plankton assemblages from the Gulf of Suez Region and correlation. - Geol. Mediter., vol. VIII, No. 2, p. 101-108.

Evans, A.L. and Moxon, I.W. (1986): Gebel Zeit chronostratigraphy; Neogene syn-rift sedimentation a top a long-lived paleohigh: 8th E.G.P.C. Exploration Seminar, Cairo, Egypt, 23 p.

Evans, A. L: 1988. Neogene tectonic and stratigraphic events in the Gulf of Suez rift area, Egypt. Tectonophysics, 153, 235-247.

Faris, M., Samir, A.M. and Shabaan, M., (2007): Calcareous nannofossil biostratigraphy of the subsurface Miocene sequence, northeast Nile Delta, Egypt. 5th International Conference on the Geology of Africa, Vol.1, 1 - 31 .

Faris, M, Samir, A. M., and Shabaan, M, (2009): Calcareous nannofossil biostratigraphy of the lower and middle Miocene sequence in the Gulf of Suez area, Egypt. 6th International Conference on the Geology of Africa, Vol. VII, 17 -44.

Farouk, S., Ziko A., Eweda. S. and Said, A. E. (2014): Subsurface Miocene sequence stratigraphic framework in the Nile Delta, Egypt. Journal of African Earth Sciences, Vol. 91, 89-109.

Ghorab, M.A., (1964): Oligocene and Miocene rock stratigraphy of the Gulf of Suez region. E.G.P.C. Start. Committee, Cairo, p. 1-142.

Ghorab A. \& Marzouk M. 1967: A summary report on the rock stratigraphic classification of the Miocene non-marine and coastal facies in the Gulf of Suez and Sea Coast. Unpublished Report. Egyptian General Petroleum Co-operation Egypt, $1-601$.

Grafunkel, Z. \& Bartov, Y. (1977): The tectonics of the Suez Rift. Geol. Surv. Israel Bull. $71,1-44$.

Gran, H. H. \& Braarud, T (1935): A quantitative study of the phytoplankton in the Bay of Fundy and the Gulf of Maine (including observations on hydrography, chemistry and turbidity) Jour. of the Biol. Board of Canada, vol. 1, p. $279-467$.
Haggag, M.A. Youssef, I. \& Salama, G.R. (1990): Stratigraphic and Phylogenetic relationships of Miocene planktonic foraminifera from the Gulf of Suez, Egypt. Middle East Research Center, Ain Shams University, Earth Science Series, 4: 22-40.

Hewaidy, A.A., Farouk, S., and Ayyad, H.M., (2013): Foraminifera and sequence stratigraphy of Burdigalian- Serravallian succession on the eastern side of the Gulf of Suez, southwestern Sinai, Egypt. N. Jb. Geol. Paleont. Abh. Vol. 2, 151-171.

Hewaidy, A.A., Mandur, M.M., Farouk, S., El Agroudy, I.S., (2016): Integrated planktic stratigraphy and paleoenvironments of the LowerMiddle Miocene successions in the central and southern parts of the Gulf of Suez, Egypt. Arab J Geosci, 9:159.

Holcovkà, K., 2013: Morphological variability of the Paratethyan Oligocene-Miocene small reticulofenestrid coccolites and its paleoecological and paleogeographical implications. Acta Palaeontologica Polonica, Vol.58 (3), 651 -668.

Iaccarino, S. (1985): Mediterranean Miocene and Pliocene planktic foraminifera. Plankton Stratigraphy. Cambridge University Press, 283 -314.

Ied, I.M., Holcová K.A and Abd-Elshafy, E., (2011): Biostratigraphy and paleoecology of the Burdigalian-Serravallian sediments in Wadi Sudr (Gulf of Suez, Egypt) comparison with the Central Paratethys evolution. Geologica Carpathiea, June, Vol.62 (3), $233-249$.

Jenkins, D.G. (1967): Planktic foraminifera zones and new taxa from Danian to Lower Miocene of New Zealand. -New Zealand J Geol. Geophysics., vol. 816, p. 1088-1126, text figs. 1-15.

Kennett, B.A and Srinivasan, M.S., (1981): A review of Neogene planktonic foraminiferal biostratigraphy; applications in the Equatorial and South Pacific, in Warme, J.E., Douglas, R.G., and Winterer, E.L., eds., The Deep-Sea Drilling Project: A Decade of Progress. Tulsa, Society of Economic Paleontologists and Mineralogists, Vol.32,395 - 432.

Kennett B.A, Srinivasan M.S., (1983): Neogene planktonic foraminifera. A phylogenetic Atlas, p 61.

Kerdany, M.T. (1967): Note on the planktic foraminiferal zonation of the Miocene in the Gulf of Suez Region U.A.R-Comm. Mediter. Neog. Stratig. p. 157-166.

Le Roy, L.W. (1939): Some small foraminifers, ostracoda and otoliths from the Neogene ("Miocene") of the Rokan-Tapanoeli area, Central Sumatra. Natuurk. Tijdschr. Nederl. Indie, p. 99. 
Macfadyen, W.H., (1931): Miocene Foraminifera from the Clysmic Area of Egypt and Sinai. Egyptian Government Press Geological Survey, Egypt, pp. 1-149.

Mandur, M.M., (2004): Stratigraphical and paleontological studies on some Miocene successions of southwest Sinai, Egypt. Unpublished Ph.D. Thesis, Ain Shams University, 1 - 220.

Mandur MM 2009: Calcareous nannoplankton biostratigraphy of the lower and middle Miocene of the Gulf of Suez, Egypt. Aust J Basic Appl Sci 3(3):2290-2303.

Mandur, M.M. (2015): Late cretaceous calcareous nannofossil biostratigraphy and paleoecology in the north western Desert, Egypt. Arab J Sci Eng, Vol.46-6.

Mandur, M.M. \& Baioumi, A., (2011): Planktonic Foraminifera Biostratigraphy of the Lower and Middle Miocene successions of the Gulf of Suez, Egypt. International $\mathbf{J}$ of Academic Rese 3(4):91-102

Martini, E., 1971. Standard tertiary and quaternary calcareous nannoplankton zonation. In: Proceedings of the Second Planktic Conference, vol. 2, pp. 739-785.

Marzouk A 1998: Nannofossil biostratigraphy of the subsurface Miocene sections in the Ras Budran Area, Gulf of Suez, Egypt. Neues Jb Geol Paläontol Abh 209(2):19-40.

Marzouk, A. (2009): Nannofossil biostratigraphy of Miocene sections from two wells in the Gulf of Suez, Egypt. Paläontologie, Stratigraphie, Fazies (17), Freiberger Forschungshefte, C 532, p. 101-127; Freiberg.

Moon, F. \& Sadek, H., (1923): Preliminary geological report on Wadi Gharandal area Petroleum. Research Bull. Cairo 10, 1-42.

Moon, F.W. and Sadek, H., (1925): Preliminary geological report on Gebel Khoshera area (Western Sinai). Petroleum Research Bulletin, Vol.9, 1- 40.

N.C.G.S., (National Committee of Geological Sciences) (1976): Miocene rock stratigraphy of Egypt. Journal of Geology, Egypt, Vol. 18, (1), 1 59.

Patton, T. L., Moustafa, A. R., Nelson, R. A., \& Abdine, S. A. 1994: Tectonic evolution and structural setting of the Suez Rift. In: S. M. London (Ed.), Interior rift basins; American Association of Petroleum Geologists, p. 7-55. Memoirs, 59.
Perch-Nielsen, K., (1985): Cenozoic calcareous nannoplankton. In: Plankton stratigraphy, Bolli et al., Cambridge Univ. Press, p. 427-554.

Postuma, J.A. (1971): Manual of Planktic foraminifera. - Amsterdam, Elsevier Publ. Co. - p. 1-420, text. - figs. 1-23, charts 1-3.

Sadek, S. 2001: Biostratigraphic Contrib. to the Miocene formations (Gharandal Group), North Hammam Faraun area, Sinai, Egypt. Jour. of Paleontol, vol.1, 2001, p.253-261.

Said, R. and El Heiny, I. (1967): Planktic foraminifera from the Miocene rocks of the Gulf of Suez region, Egypt. Cush. Laboratory Foraminiferal Res., (Contrib., Vol. 18 (1), p. 14-26, Pls. 5.

Soliman, A., Stjepan, C'oric', Martin, J. H., Werner, E. P. and El Beialy, S. Y.E., (2012): Lower and Middle Miocene biostratigraphy, Gulf of Suez, Egypt based on dinoflagellate cysts and calcareous nannofossils. Palynology, Vol.36 (1), 3879.

Souaya, F. (1966): Miocene foraminifera of the Gulf of Suez region U.A.R. Pt. III: Biostratigraphy. - Micropal. vol. 12, no. 2, p. 183-202.

Stainforth, R. M., Lamb, J. L., Luterbacher, H., Beard, J. H. and Jeffords, R. M. (1975): Cenozoic planktic foraminiferal zonation and characteristics of index forms. University of Kansas Paleontological Contribution, Vol. 62, 1-425.

Wade, B.S., Pearson, P.N., Beggren, W. A. and Palike, H., (2011): Review and revision of Cenozoic tropical planktic foraminiferal biostratigraphy and calibration to the geomagnetic polarity and astronomical time scale. Earth Science, Vol.104, 111 - 142.

Wasfi, S.M. (1968): Miocene planktic foraminiferal zones from the Gulf of Suez region, Egypt. - 3rd African Micropal. Collq. Cairo, p. 461476, pls. $1-3$, text-figs. $1-3$. 


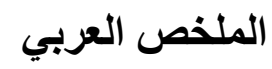

ا. ادت الدراسة التفصيلية لمنطقة راس العش الي تعريف ثلاثة نطاقات من الفورامنيفرا ونطاقان من النانوبلانكتون وهي من الاقدم للحدث Catpsydrax dissimilis Zone (M3) وعمره الميوسين الاسفل(Burdigalian) و و Praeorbulina sicana Zone (M5) وعره من الميوسين الاسفل للاوسط (Burdigalian-Langhian) و(Fohsella peripheroacuta Zone (M7) وعمره الميوسين الاوسط Serravallian) بالاضافة الي Sphenolithus belemnos Zone (NN3) و عمره الميوسين الاسفل(Burdigalian) و و (Helicosphaera ampliaperta Zone (NN4) ومره من الميوسين الاسفل للاوسط (Burdigalian- Serravallian) r. نطاقات الفور امنيفر ا و النانوبلانكتون متو افقة مع بعضها وتم مقارنتها مع تلك التي سجلت في مصر وخارجها

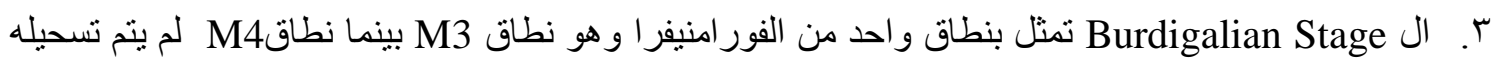
بسبب Mid-Rudeis Event وهذا النطاق يتو افق تماما مع نطاق من النانوبلانكتون NN3 و الجزء الاسفل NN4 من نطاق ك. تم تمييز بداية ال Langhian Stage اعنمادا علي بداية ظهور Orbulina suturalis بالقرب من نهاية Helicosphaera ampliaperta Zone לهور •. تميز ببداية ظهور Langhian / Serravallian تمد الفاصل بين peripheroacuta (M7) Zone في متكون البلاعيم في راس العش 1 فين 7. الاختلاف الكبير في زمن الترسيب و التعرية يدل علي حركات تكتونية مختلفة والتي استغرقت فترة كبيرة من الزمن

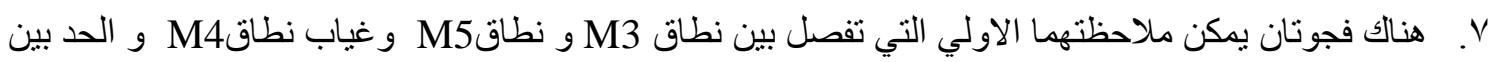

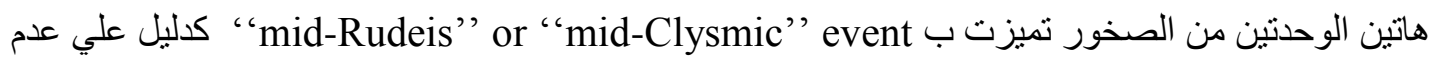

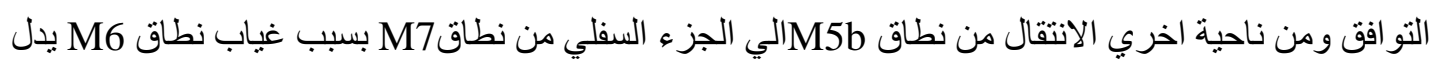

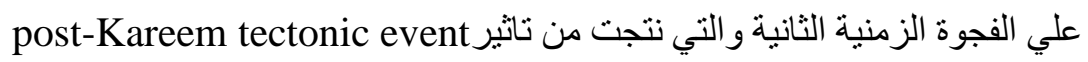

